Article

\title{
Consumer Attitude and Behavioral Intention toward Collaborative Consumption of Shared Services
}

\author{
Geena Billows and Lisa McNeill * \\ Department of Marketing, University of Otago, Dunedin 9054, New Zealand; bilge851@student.otago.ac.nz \\ * Correspondence: lisa.mcneill@otago.ac.nz; Tel.: +64-3-479-5758
}

Received: 1 November 2018; Accepted: 23 November 2018; Published: 28 November 2018

\begin{abstract}
The emerging market model of collaborative consumption, where underused resources can be collaboratively shared between consumers, is proving to be an increasingly profitable commercial business concept encouraging traditional non-sharing firms to seek models of shared access for their consumers. In terms of consumption reduction, however, the concept has seen slower uptake among consumers. For example, despite the promotion of car sharing and public transportation solutions, cities around the world report increasing car use and an increasing concentration of businesses in urban areas demanding parking spaces. Where it is known that private vehicle use in urban centers persists, this study explores consumer attitude and behavioral intention toward collaborative consumption of shared services, in the context of personal transport and the built, inner-city environment. The study reports survey data gathered from self-driving employees of businesses located in congested urban areas. Six motivational determinants of collaborative consumption and how they influence attitude and intention toward two different shared parking scenarios were explored using regression analysis. In this study, shared carparks are treated as an incremental step toward shifting more stubborn user perceptions of access over ownership in urban transport, as well as a solution to one aspect of the problems associated with increased urban density and underused land resources. Overall, the study finds a strong relationship between perceptions of ownership and risk reduction, with access models that protect a "primary" user, and allow for user flexibility, preferred by respondents. This offers clear guidelines for the development of successful shared space options in the parking context but can also be extended to other sharing service solutions.
\end{abstract}

Keywords: sharing; access economy; collaborative consumption; car parking; services; attitudes; behavioral intention

\section{Introduction}

The sharing, or access economy is a hybrid market model between owning and gift giving, characterized by multiple modes of exchange that operate at the intersection between market and non-market economies [1]. The sharing economy is characterized by temporarily accessing goods and services in place of owning them and is ideal for assets that have frequent idle capacity [2,3]. Modern consumer technologies facilitate the sharing economy, where a service provider can match sharing consumers with one another in a simple, user-friendly fashion (e.g., [2,3]), negating concerns around system ease. While sharing is accepted as a rapidly growing business phenomenon, studies that explore consumer attitude and intention regarding the sharing economy are still limited [4], and little research examines sharing in the service domain [5].

The access economy concept is becoming increasingly appealing to cities that face challenges around increased population density [6,7]. Urban centers are more crowded than ever, and land resources are strained. Where access models such as car sharing or public transportation are encouraged to reduce on-road congestion, there remains the problem of allocation of land resources to 
effectively idle property (that of private car parks, not always used for the duration of a workday). In small to medium sized cities, home to a quarter of the world's population, this issue is particularly critical, as these cities "often have fewer resources to implement new transport measures and can be more vulnerable to fluctuations in the world economy" [8]. In developing economies particularly, rapid economic growth, coupled with population shift toward urban areas and increased personal incomes has resulted in extremely rapid rises in car ownership (car ownership increased more than 15 times in Bangkok in the period 1980-1995, compared with 2.2 times increase in the same period in London, and 1.56 times increase in Tokyo) [9]. New Zealand, in a similar fashion to North America [10], has a private car orientation, with public transportation viewed as a service for particular social segments. Unlike Europe, which has an embedded public transport ethos and, increasingly, an emphasis on alternative forms of transport such as bicycles [10], New Zealanders tend to own multiple cars per household and drive to work, school and leisure activities. Building legislation in New Zealand also mandates a relatively high number of parking spaces per building, increasing the already urgent pressure on land in urban centers (e.g., 1 park $/ 40 \mathrm{~m}^{2}$ gross floor area for office buildings, one park $/ 20 \mathrm{~m}^{2}$ for retail spaces less than $5000 \mathrm{~m}^{2}, 1$ park $/ 20 \mathrm{~m}^{2}$ for supermarkets and one park $/ 10 \mathrm{~m}^{2}$ for restaurants, bars and cafes) [11].

Sustainability action in relation to parking is one of the key influencers on development of car management facilities in urban areas [12]. Where the term "car sharing" is widely used in everyday discussion [6], "access-based consumption" [13] is not. What this signifies is the lack of consideration of sustainability problems that are less visible-such as the problem of where to put idle vehicles (shared or otherwise) in congested urban spaces, and how to efficiently allocate land resources to the problem of car parking. Despite the promotion of car sharing and public transportation solutions, cities around the world report increasing car use and an increasing concentration of businesses in urban areas demanding parking spaces for their employees that exceed current supply [14]. Situations of under-capacity exist in multiple forms within the transport framework and are cited to cost millions of dollars in both lost efficiency as well as environmental impact [10]. Evidence to date highlights the difficulty in identifying a single solution, when urban forms are so diverse. What is known, however, is that uncontrolled low-density sprawl is not a sustainable option [8]. If vehicle use is not decreasing in urban centers, legitimizing this action by providing more car parks is not a solution that sits well within the overall framework of a sustainable world. Recent research on sustainable urban transport initiatives suggests that a more pragmatic approach to managing the transport problem, rather than an idealistic one, is more likely to result in measurable success in behavior change [8]. If one considers shared carparks as a temporary action that may begin to shift more stubborn user perceptions of access over ownership (and thus be the first step toward car sharing or alternative transport options), the model could be critical in reducing unsustainable land use in urban centers.

The sharing economy can be viewed within the lens of service-dominant logic, which proposes that consumers do not necessarily want a good for its tangible offerings as in ownership, but rather for the intangible service, benefit or experience it provides. It is likely that a changing consumer attitude toward access and sharing as alternative modes of consumption will continue to further the growth of the sharing economy. Where the proposed park-sharing option is classes as "soft" behavior change measure, the potential for legislative change as well as attitude shift toward sustainable behavior on the part of consumers is of prime interest in this study. However, part of the issue in extending access economy concepts, such as shared vehicles, is centered in the focus of current discussions around sharing; which tends to be on access to physical goods (shared tools, rented clothing etc.), and facilitated service exchanges where one consumer is the provider, the other the consumer (e.g., Airbnb, Uber). Far less research emphasizes peer sharing of services provided by a third (often commercial) provider. This research takes one such service, that of car parking, and examines consumer responses to shared alternatives to standard parking agreements. The notion of a collaborative service network is explored and determinants of user participation essential to such a network detailed in the park-sharing models identified in relation to user and community benefit. The current project seeks to identify what 
general attitudes consumers express toward the sharing of third-party services with other consumers, how these attitudes are expressed in the applied context of car-parking services, and the primary perceptual barriers to consumer sharing of third-party services.

\section{Theory}

\subsection{Private Car Usage and the Urban Environment}

Consumption is bound in ideas of property and ownership [13]; however, underuse of goods and services promotes sharing as a sustainable and economically efficient alternative to traditional forms of ownership-based consumption [3]. A shift in perception of ownership as being the most desirable way to access products and services means that consumers who were once defined by their possessions are becoming increasingly accepting of temporary access to goods [13]. This concept of selling the use, not the product (e.g., [15]) is complicated, as without ownership rights over the resource (e.g., [6]), there is also no control of that resource. Personal independence and security are said to be drivers of a need for ownership of goods and services [16,17], thus any threat to this autonomy in use may detract from perceived advantages of any shared system of use. However, participation in online platforms, where the notion of sharing is heavily emphasized and encouraged, has played a role in making consumers more accepting of sharing $[6,18,19]$. Furthermore, increased concerns regarding the environment and responses to financial crises have led many consumers to seek out more sustainable forms of consumption, contributing to positive attitudes regarding access models versus ownership $[4,6,20]$.

Where private vehicle usage is considered a threat to the future human environment, several policy measures designed to reduce or change usage have been developed over the last few decades [21]. These measures can be classified as "hard" or "soft": the core differential being the level of choice given to the users of any proposed system. Where "hard" measures, such as increased cost of car use, rationing of vehicle use and mandated sharing have proven to be ineffective in changing behavior [22], increasingly, "soft" measures are being considered as more persuasive. "Soft" vehicle usage behavior moderators can be described as "personalized travel planning" [21] and take into account the personal needs and attitudes of the end user, as well as the sustainability needs of the environment and wider community. "Soft" sustainability measures include product-service systems (PSS), a specific type of value proposition offered by businesses that enable sharing between consumers [23]. PSS allow the user to pay for the benefit of a product, without needing to own the product outright, whereby multiple products owned by a company can be shared among multiple consumers [2]. The implementation of a shared access parking system would thus operate as a PSS, and as such, value may be co-created between the provider and the customer, as well as between customer dyads or groupings that "share" the original service (with mutual benefit for each). As a consumer gains experience in using such a system, preference for other types of sharing arrangement (such as vehicle sharing) may increase. Furthermore, as a consumer experiences the psychological benefits of sustainable behavior, this may lead to increased behavior change toward sustainability more generally.

\subsection{Collaborative Consumption and the Access Economy}

PSS falls under the umbrella of collaborative consumption and the sharing economy, and, in modern marketplaces, often occur in online communities that operate with ease and for little cost ([4] p. 194). Web-based collaborative consumption (CC) platforms simply act as "economical-technological coordination providers", not controlling the inherently social activity of sharing, but facilitating it [3]. Note the multiplicity of the term "sharing" in this context: in everyday understanding, the term "sharing" is generally altruistic and implies no payment. Yet although the notion of the "sharing economy" has become the widely recognized term for market models, some suggest that "access economy" may be more appropriate, insisting that once sharing is market-mediated, it is no longer sharing at all [6]. Access, however, can be underlined by economic exchange and reciprocity, and thus 
access-based consumption has been defined as, "transactions that may be market-mediated in which no transfer of ownership takes place" ([6] p. 881). This is a more appropriate terminology for the examination of "shared" provider-generated services.

CC encompasses both business-to-consumer (B2C) services as well as consumer-to-consumer (C2C) services, with C2C services usually facilitated by an external provider [4]. Early CC theory was primarily focused upon exploring the "communal" nature of $\mathrm{CC}$, that which involves peer-to-peer transactions between consumers, as collaborative contexts often require communal links to be fostered between participating individuals to co-create the service outcomes (e.g., [2,6]). Many of the early C2C collaborative options were organically fostered among private individuals with no intervention from a facilitating third party, centered on the idea of interacting with a group of like-minded individuals $[2,4,6]$. However, emerging research suggests that for those more recent forms of CC that are provider-generated and market-mediated, consumers demand anonymity and do not want to foster relationships with other consumers or the provider [6].

In CC situations where consumers are engaging in economic transactions, the main motivation for engagement is said to be that of the personal utilitarian value the access-based service may provide, such as reduced expenses, rather than contributing to a collective good [6]. Individuals who access communal resources may act in their own self-interest even though they would be better off by collaborating with one another, in line with "tragedy of the commons" theory [24]. Consumers are "disengaged from carrying out their responsibility to ... others using [the service]" ([6] p. 891). Further research should therefore explore the nature of these provider-generated "pseudo-CC" services that are designed purely for commercial advantage. Exploration of the role of "ownership", and how consumers in such provider-generated shared access models perceive it, would also be beneficial. Does disassociation from other users of the service make it easier for consumers to separate themselves from any feelings of ownership?

\subsection{Motivation for Engagement with Sharing Economy Models}

Research concerning motivation for engagement in sharing economy practices is relatively recent and thus limited. Proponents of collaborative consumption identify its two key drivers as motivation to save money, and environmental preservation (e.g., $[3,18,25])$. Thus, both altruistic as well as individualistic reasons act as key motivators for engagement in collaborative consumption [26]. In addition, research is required to further understand the relationship between consumer attitude toward CC practices, and their actual intended behavior.

Hamari et al. found that while attitude influenced behavioral intention to engage in CC, it was to a smaller degree than usually found between these constructs, possibly indicating a discrepancy between attitude and actual behavior [3]. Previous literature has paid attention to the discrepancy between environmentally sustainable attitudes and actual sustainable behavior. The Futerra study highlights this, in which $30 \%$ of consumers stated that they would consume ethically, but only $3 \%$ actually did [27]. While consumers may hold positive attitudes toward a sustainable activity, this attitude may not necessarily translate into action. The theory of reasoned action is used to make predictions about actual behavior, based on an individual's stated behavioral intention. Attitude, in combination with subjective norms, are said to determine this intention [28]. Further research regarding the possible attitude-behavior gap in the context of the present study will provide a deeper understanding of how consumers perceive the notion of sustainability in a shared services context.

\subsection{Research Hypotheses}

\section{General Intention toward Collaborative Consumption (CC):}

Attitude and intention toward collaborative consumption practice more generally can be assumed to play a significant role in influencing how one might respond to a contextual sharing economy 
offer, yet there is little research that examines the two in conjunction. Thus, the following hypothesis are tested:

Hypothesis 1a. Intention to engage in CC more generally will significantly predict attitude (+ve) toward shared car-parking services;

Hypothesis $\mathbf{1 b}$. Intention to engage in CC more generally will significantly predict behavioral intention $(+v e)$ toward shared car-parking services.

\section{Personal Reputation:}

Hamari et al. explored the influence of expected gains in personal reputation from participating in collaborative consumption actions on consumer attitude and behavioral intention. These findings indicated that reputation did not share a significant relationship with either attitude or intention, however the study did not examine a specific context applied to the normal lifestyle of the participating individuals [3]. Thus, it is proposed:

Hypothesis 2a. Perceived gains in personal reputation from engaging in CC will significantly predict attitude $(+v e)$ toward shared car-parking services;

Hypothesis $2 \mathbf{b}$. Perceived gains in personal reputation from engaging in CC will significantly predict behavioral intention $(+v e)$ toward shared car-parking services.

\section{Sustainability:}

Some literature notes sustainability as one of the main reasons that people engage in CC, as an altruistic motivation $[3,18]$. Yet other research has found environmentalism not to have a direct relationship with one's behavioral intention toward a CC service [3,4]. The impact of environmentalism on consumer attitude, then, is contradictory in the literature, emphasizing the need for further examination of this issue, thus:

Hypothesis 3a. Perceived sustainability of CC will significantly predict attitude $(+v e)$ toward shared car-parking services;

Hypothesis $3 \mathbf{b}$. Perceived sustainability of CC will significantly predict behavioral intention (+ve) toward shared car-parking services.

\section{Financial Drivers:}

One qualitative study found reduced expenses to be a main motivation for consumer engagement with CC [6]. However, tests of this relationship have been contradictory. One study found that in B2C car sharing, cost savings increased the likelihood of satisfaction with the service but had no significant relationship with intention to choose the sharing option again [4]. Alternatively, Hamari et al. found the opposite [3]. Anticipated economic benefit did not have a significant effect on attitude to CC but did positively influence intention to participate. It is expected that this will be a key driver in the context of shared parking, as leasees of car parks in cities pay a relatively substantial monthly fee for their parks, thus:

Hypothesis 4a. Financial benefit of CC will significantly predict attitude toward (+ve) shared car-parking services;

Hypothesis $4 \mathbf{b}$. Financial benefit of CC will significantly predict behavioral intention (+ve) toward shared car-parking services. 


\section{Difficulties in CC:}

Literature only marginally touches on perceived barriers of engaging in CC, and what has been explored is only applicable to privately owned tangible goods (i.e., attachment to one's belongings and trust in others using them) $[7,23]$. Hence a need to explore perceived barriers to uptake of CC services in this study. Perceived difficulty of CC, and perceived restrictions that its usage might cause a user, are examined in the current study, thus:

Hypothesis 5a. Perceived difficulties in CC will significantly predict attitude (-ve) toward shared car-parking services;

Hypothesis $5 \mathbf{b}$. Perceived difficulties in CC will significantly predict behavioral intention (-ve) toward shared car-parking services.

\section{Relationship between Attitude and Behavior:}

Consumer behavior theory repeatedly identifies an attitude-behavior gap in many consumption areas, such as between environmental attitude and sustainable behavior. In the specific context of CC, while attitude influenced intention to engage in CC, it was to a smaller degree than usually found between these constructs, possibly indicating a discrepancy between reported attitude and actual behavior [3]. Perceived sustainability had the strongest relationship with attitude toward CC, while economic benefits were a stronger motivator for behavioral intention toward CC-this discrepancy providing an explanation for the weak correlation identified between attitude and intention [3]. However, the prior study looked at attitude and intention toward CC in general, not toward a specific context such as the current study, thus:

Hypothesis 6. Attitude (+ve) toward shared car-parking services will significantly predict behavioral intention (+ve).

\section{Methodology}

\subsection{Survey}

A survey method was used, consistent with previous collaborative consumption studies (e.g., [3,4]). Survey items were adapted from existing literature, and, at the beginning of the survey, collaborative consumption in this context was defined (to ensure all respondents had an equal understanding of what may be a relatively unfamiliar concept). The survey was split into two sections, the first of which asked general attitudinal questions toward collaborative consumption, the second questioned attitudes and behavioral intentions toward two applied shared car-parking scenarios. A scenario-based process is useful in stated preference survey measurement, as individuals are said to perceive service concepts as a whole, rather than a sum of separate factors, necessitating complete, alternative specifications of concepts [29].

Scenario One was designed to simulate what a shared access car-parking model might look like, with room for respondents to consider preferences related to such a model, such as peer-to-peer management of parks versus employer/provider management. The scenario does not indicate payment, leaving room for questions that explore both paid and non-paid options: "Rather than having a dedicated car park at your place of work, a pool of carparks are shared among like-minded consumers, and you use an app on your smartphone to find an empty space when you need it". Scenario Two was designed to simulate a more traditional form of car parking, but again does not indicate payment: "There is a dedicated car park for you at your place of work, reserved for you only between the hours of 7:30 a.m. and 5:30 p.m. on weekdays. Outside of these hours, the car park is used by others, and you have no priority rights".

Criterion for inclusion in the study were that the respondent drove a vehicle to work on one or more days per week and used a dedicated car park (either personally leased (from a private or public-access provider), or provided gratis by their firm), that was held for their use only throughout 
the working week. In this sense, the sample was purposive, not random, with employees of large organizations in the selected city targeted for response. The survey was web-based, employed a Likert-scale format, and took participants around ten minutes of their time in total. Despite the limitations of a web-based survey method, this format was selected to aid in ease of response by participants (a direct link to the survey was included in the approach email, and the online survey was formatted for response via smartphone as well as desktop computer), and to align with the proposed collaborative use model outlined in scenario one, which uses a smartphone facilitated process for carpark allocation.

Where the survey employs a stated preference model, a key limitation of this is assessing the likely gap between actual behavior and stated preference for variables provided in the study. However, in transport research, stated preference is often employed over revealed preference models due to: difficulty in revealed preference obtaining sufficient variation in preference data; difficulty in estimating model parameters; an inability to estimate demand under theoretical conditions; and the requirement that explanatory variables be objective only (and thus restricted to primary service variables) [29].

\subsection{Respondents}

Responses were collected from 116 individuals who use private parking as part of their day-to-day work habit. Where the sample was purposive (requiring use of a paid car park, for work purposes, on a regular basis), it was difficult to ascertain a representative population size. Thus, the survey was disseminated without a pre-determined sample size and sent to all employees of the firms included in the population pool. The resultant final sample size was, however, consistent with similar sample sizes in previous CC research-e.g., [3]). Respondents were recruited via direct email to organizations, during the months of June to September 2016, and provided with an anonymous link to the survey. The survey was directed toward staff of large-scale organizations in four major New Zealand cities (Auckland, Wellington, Christchurch, and Dunedin), with dedicated parking resources on-site. Where large organizations offer staff car parks in a lease format, these parks are often idle of cars, as users may not require the park each workday, or for full days. Furthermore, at the end of the workday, these dedicated private parks often sit empty of vehicles, while pressure increases on public parking services. Despite innovations such as car sharing or increased public transport options, as organizations and cities grow, demand for individually allocated employee parks has increased; however, it is clear that this is not an efficient use of land resources in the inner city. Thus, shared parking services offer a potentially attractive solution to individuals regularly using private vehicles within highly congested urban areas.

\subsection{Analysis Process}

Multiple regression analysis was the primary analytical method used to test the stated hypotheses of the study. This technique is used to predict and measure the influence of a set of independent variables on a dependent variable, and thus is useful for understanding how different motivational determinants will influence attitude and behavioral intention toward the shared parking concept [30]. Factor analysis was initially employed to reduce the number of variables to be included in the regression. The results of these statistical analyses are reported in the following section.

\subsection{Factor Analysis}

Principal axis factor analysis was employed to assign the survey items regarding each construct to a single representative variable for use in regression. Five factor analyses were carried out in total. The first was regarding the key motivational determinants of CC. Two factor analyses were then used to reduce attitude toward each of the shared car-parking scenarios to single variable, and two further factor analyses were carried out regarding behavioral intention toward each of these two scenarios. Direct oblimin was the method of rotation used. The mean and standard deviation for each factor may be found in Appendix B. 
In reducing the number of variables, those factor loadings with a value below 0.4 and those factors that had cross-loadings were removed iteratively until a final matrix was reached. The Kaiser-Meyer-Olkin (KMO) measure of sampling adequacy was above 0.6 for each factor analysis, and total variance explained was above $60 \%$, the recommended minimum in social sciences, for both attitude and behavioral intention regarding Scenario One [30]. However, total variance explained was below $60 \%$ for both attitude and behavioral intention regarding Scenario Two, and thus caution must be taken when interpreting the results. Cronbach's alpha was used to test the reliability of each derived factor and was found to be above 0.7 for each factor, excluding the construct of behavioral intention toward Scenario Two, where the Cronbach's alpha was 0.594. The suggested lower limit for a Cronbach's alpha is 0.7 [31]. Values below this require caution taken when interpreting [31]. Details for each factor may be found in Appendix A. Five factors were extracted from the first factor analysis regarding motivations toward CC in general. The labels given to the factors, based on the variables that loaded on each, were "Intention toward CC in general", "Reputation", "Sustainability", "Financial Drivers", and "Difficulties in CC" respectively. One factor was extracted for each attitude and behavioral intention toward both shared parking scenarios One and Two. The variables included in each factor are detailed in Appendix A.

\subsection{Regression Analysis}

Three regressions were carried out for each proposed car-parking scenario to test the hypotheses of the study. Motivational determinants for engaging in CC acted as the independent variables in testing against both consumer attitude and behavioral intention toward shared car parking. Attitude was then used as the independent variable when testing the existence of a relationship with behavioral intention. In checking the assumptions of the regression models, homoscedasticity and linearity were met for each regression, while tests for normality found minimal violations in some instances, which must be taken into consideration when interpreting the results (refer to p-plots and scatterplots in Appendix $C$ for illustration of assumptions).

\section{Results}

\subsection{Parking Scenario One}

For car-parking Scenario One, the shared access model, motivational determinants of CC accounted for $29.5 \%$ of the variance in attitude toward the shared car-parking service, and $44.5 \%$ of the variance in behavioral intention to use the service. The results are summarized in Table 1 . Intention toward CC in general was found to significantly predict attitude toward Scenario One, supporting H1a, while both intention toward CC $(\beta=0.555)$ and perceived gains in reputation ( $\beta=0.203$ ) were found to significantly predict behavioral intention to shared car parking, supporting $\mathrm{H} 1 \mathrm{~b}$ and $\mathrm{H} 2 \mathrm{~b}$. Attitude toward car-parking Scenario One significantly predicted behavioral intention toward usage of it, supporting H7, where the regression model had an explanatory power of $70.7 \%$, with a standardized coefficient $(\beta=0.843)$, indicating a positive relationship.

Table 1. Scenario One: Shared access model.

\begin{tabular}{cccccc}
\hline Independent Variable & $\begin{array}{c}\text { Dependent } \\
\text { Variable }\end{array}$ & Model Sig. & Adjusted $\boldsymbol{R}^{2}$ & $\begin{array}{c}\text { Standardized } \\
\text { Coefficients }(\boldsymbol{\beta})\end{array}$ & Sig. $(\boldsymbol{\beta})$ \\
\hline Attitude toward CC & Attitude & 0.000 & 0.295 & -0.495 & 0.000 \\
Reputation & & & -0.086 & 0.378 \\
Sustainability & & & -0.035 & 0.762 \\
Smartphone Capability & & & -0.088 & 0.384 \\
Financial Drivers & & & 0.163 & 0.090 \\
Difficulties in CC & & & 0.057 & 0.642 \\
Intention toward CC & Behavioral & \multirow{2}{*}{0.000} & 0.445 & 0.555 & 0.000 \\
Reputation & Intention & & & 0.203 & 0.021 \\
Sustainability & & & & -0.126 & 0.694 \\
Financial Drivers & & & & -0.055 & 0.141 \\
Difficulties in CC & & & & 0.843 & 0.000 \\
Attitude & Behavioral & \multirow{2}{*}{0.000} & 0.707 & & \\
\hline
\end{tabular}




\subsection{Parking Scenario Two}

For car-parking Scenario Two, the non-shared, traditional usage model, determinants of CC accounted for $12.4 \%$ of the variance in behavioral intention to use shared car-parking services. The results are summarized in Table 2. For the relationship between CC determinants and the dependent variable of attitude, the model was not significant, and thus attitude to this shared parking scenario cannot be significantly predicted by the key motivational determinants of CC. Perceived sustainability ( $\beta=-0.371)$, as well as difficulties in CC $(\beta=0.295)$, were found to significantly predict behavioral intention toward the shared parking concept, confirming $\mathrm{H} 1 \mathrm{~b}$ and $\mathrm{H} 6 \mathrm{~b}$; however a Cronbach Alpha of below 0.7 indicates that caution should be taken in interpreting these predictions. As with Scenario One, attitude toward the non-shared car-parking concept significantly predicted consumer behavioral intention toward using it, with $44.1 \%$ of the variance accounted for and thus confirming H7 (standardized coefficient $\beta=0.669$ ).

Table 2. Scenario Two: Non-shared access model.

\begin{tabular}{cccccc}
\hline Independent Variable & $\begin{array}{c}\text { Dependent } \\
\text { Variable }\end{array}$ & Model Sig. & Adjusted $\boldsymbol{R}^{2}$ & $\begin{array}{c}\text { Standardized } \\
\text { Coefficients }(\boldsymbol{\beta})\end{array}$ & Sig. $(\boldsymbol{\beta})$ \\
\hline Attitude toward CC & Attitude & 0.083 & 0.064 & 0.241 & 0.119 \\
Reputation & & & & 0.097 & 0.399 \\
Sustainability & & & -0.017 & 0.593 \\
Financial Drivers & & & -0.181 & 0.110 \\
Difficulties in CC & & & 0.346 & 0.013 \\
Intention toward CC & Behavioral & 0.011 & 0.124 & 0.129 & 0.385 \\
Reputation & Intention & & & 0.162 & 0.148 \\
Sustainability & & & -0.371 & 0.005 \\
Smartphone Capability & & & 0.139 & 0.213 \\
Financial Drivers & & & -0.081 & 0.455 \\
Difficulties in CC & Behavioral & \multirow{2}{*}{0.000} & 0.441 & 0.295 & 0.026 \\
Attitude & Intention & & 0.669 & 0.000 \\
\hline
\end{tabular}

Table 3. Summary of Support for Hypotheses by Scenario.

\begin{tabular}{|c|c|c|}
\hline Hypotheses & Scenario 1 (Shared Access) & Scenario 2 (Traditional Usage) \\
\hline $\begin{array}{l}\text { H1a. Intention to engage in CC more generally will } \\
\text { significantly predict attitude toward shared car-parking services; } \\
\text { H1b. Intention to engage in CC more generally will } \\
\text { significantly predict behavioral intention toward shared } \\
\text { car-parking services. }\end{array}$ & $\begin{array}{l}\text { Supported } \\
\text { Supported }\end{array}$ & $\begin{array}{l}\text { Not Supported } \\
\text { Not Supported* Cronbach alpha } \\
\text { below } 0.7\end{array}$ \\
\hline $\begin{array}{l}\text { H2a. Perceived gains in personal reputation from engaging in } \\
\text { CC will significantly predict attitude toward shared } \\
\text { car-parking services; } \\
\text { H2b. Perceived gains in personal reputation from engaging in } \\
\text { CC will significantly predict behavioral intention toward shared } \\
\text { car-parking services. }\end{array}$ & $\begin{array}{l}\text { Not supported } \\
\text { Supported }\end{array}$ & $\begin{array}{l}\text { Not supported } \\
\text { Not supported }\end{array}$ \\
\hline $\begin{array}{l}\text { H3a. Perceived sustainability of CC will significantly predict } \\
\text { attitude toward shared car-parking services; } \\
\text { H3b. Perceived sustainability of CC will significantly predict } \\
\text { behavioral intention toward shared car-parking services. }\end{array}$ & $\begin{array}{l}\text { Not supported } \\
\text { Not supported }\end{array}$ & $\begin{array}{l}\text { Not supported } \\
\text { Supported }\end{array}$ \\
\hline $\begin{array}{l}\text { H4a. Financial benefit of CC will significantly predict attitude } \\
\text { toward shared car-parking services; } \\
\text { H4b. Financial benefit of CC will significantly predict } \\
\text { behavioral intention toward shared car-parking services. }\end{array}$ & $\begin{array}{l}\text { Not supported } \\
\text { Not supported }\end{array}$ & $\begin{array}{l}\text { Not supported } \\
\text { Not supported }\end{array}$ \\
\hline $\begin{array}{l}\text { H5a. Perceived difficulties in CC will significantly predict } \\
\text { attitude toward shared car-parking services; } \\
\text { H5b. Perceived difficulties in CC will significantly predict } \\
\text { behavioral intention toward shared car-parking services. }\end{array}$ & $\begin{array}{l}\text { Not supported } \\
\text { Not supported }\end{array}$ & $\begin{array}{l}\text { Not supported } \\
\text { Supported }\end{array}$ \\
\hline $\begin{array}{l}\text { H6. Attitude toward shared car-parking services will } \\
\text { significantly predict behavioral intention. }\end{array}$ & Supported & Not supported \\
\hline
\end{tabular}

\section{Discussion and Conclusions}

With the main aim of the research at hand being to seek an understanding of the range of attitudes and intentions toward shared car parking, the findings of this study indicate the influence that different 
motivational determinants of CC have in this context. The current study is the first to examine how the general perceptions that consumers hold toward the concept of CC may influence attitude and intention regarding a specific "pseudo-CC" context. In this study, two different car-parking scenarios were proposed, each based on different forms of access - the first in which access is shared equally between all consumers, and the second in which a consumer pays to have primary access to a park and leaves it idle during non-use periods. Both scenarios presented in the current study found attitude to significantly predict behavioral intention. While consumers would be prepared to use either scenario, the preferred model was Scenario Two, the non-sharing model, highlighting the stubbornness of existing consumption habits around personal transport (see Table 3).

The results also provide insight into how consumers in a service context perceive the nature of their ownership. In sharing situations where all consumers have equal access rights to a tangible good, consumers do not perceive themselves as having a sense of shared ownership over the good as they are conscious of the other "faceless" consumers that use it [6]. This aligns with the access model seen in Scenario One. However, in Scenario Two, the consumer response to ownership differs. Perceived difficulties in CC were found to significantly predict both attitude and intention toward Scenario Two, highlighting how consumer fear of problems with shared models drive preference for traditional modes of consumption. Unlike the equal access model, in which consumers do not perceive themselves as being an owner, in a model where consumers are able to have primary access rights over other consumers, they experience perceptual "ownership", even though they are actually leasing from a provider. It is possible therefore, that those barriers identified in the sharing of tangible goods, such as attachment to property that consumers experience feelings of "ownership" over, are also applicable in services contexts.

In examining the difference in results between Scenario One and Scenario Two, it appears that the consumer intention toward the equal access model of Scenario One may be driven by a combination of subjective norms and attitude. Intention toward CC in general, as well as perceived gains in reputation from using CC, were both positive predictors of behavioral intention toward the shared model, while attitude toward the shared model was positively related to intention. Where subjective norms are defined as perceived social pressure to engage or not engage in a particular behavior [28], the response regarding behavioral intention may have been influenced by the fact that if consumers were to use this equal access model, they would feel good about themselves and their reputation among their peers. As gains in reputation (a subjective norm) was found to significantly predict behavioral intention in this context, it appears that attitude and subjective norms both contribute to overall intention toward this scenario. If consumers believe that engaging in CC will increase their reputation and have a positive attitude toward the specific equal access model context, ultimately, they are more likely to select the equal access model. In the specific context of car parking, however, the risk factor of perceived problems (such as not finding a park and being late for work or an important meeting), when combined with the requirement of significant change in existing habits, prevents selection of the shared access model in most cases.

This is an important finding, as it highlights the role of perceived risk as a barrier to behavioral change. Even as a "soft" (non-legislative) measure, shared car parking would need to be implemented in a fashion that mitigates potential problems such as peak demand and overflow or excess demand. Information and communications technology (ICT) solutions that provide proxy risk reduction for individual consumers may help in this regard. Scenario Two, the non-shared, traditional model may be preferred in this context because consumers may not perceive the benefits inherent in the shared access model as being substantial enough to outweigh perceived risks. In such a model, only paying for their actual use of the park may reduce costs to the customer, allow them to act more sustainably, and foster a sense of community when collaborating with other consumers who use the service. Yet, despite these benefits, in this context consumers still prefer the traditional, non-shared model. As consumers in this context are familiar with the traditional provider-leasee model of car parking that currently exists, they may not perceive any worthwhile benefit of switching to an equal 
access model. This, when considered outside of the parking context, but within the broader transport context, raises important questions as to how shared access models can be successfully implemented. We know that uptake of CC transport models such as car sharing has been slow in urban areas, despite increasing pressure on the built environment. Studies suggests this is due in part to the limited usefulness of "hard" behavior change measures in providing reasonable solutions to personalized travel needs [22]. This study, when applied in a broader context, suggests that uptake of shared transportation models will be negatively impacted by the perceived risks associated with the outcomes of a change in behavior, and that reduced costs or social pressure to change are not strong enough motivators to outweigh a consumer desire for control (and thus risk reduction). Aforementioned ICT solutions allow for flexibility by consumer in travel demands, behavior patterns and urban mobility changes [32]—offering a solution most likely to overcome the barriers to shared service uptake identified in this study.

As Hardin's "tragedy of the commons" states, human behavior is primarily driven by rational behavior and self-interest; even though collaborating with one another would make people better off [24]. In line with this, as found in previous CC research, consumers in the non-shared parking context choose to act in their own interest, even though they would be contributing to a collective utility by collaborating with one another $[3,6]$. Consumers in this study were not strongly interested in contributing to a collective utility or fostering a sense of community with other users of the service, but rather, were driven by individualistic motivations, conforming to the norms of market-mediated consumption. However, in contrast with previous CC studies, consumers in the non-shared parking scenario are not driven by the "typical" determinants $[3,4,6]$ that serve a user's self-benefit, as financial motivation was not found to have a significant effect on intention. This is an important finding, as it suggests that, in this, and related contexts (such as car sharing) consumers are driven by individualistic motivations toward perceived risk reduction.

From a managerial or policy perspective, the transition from traditional non-sharing services to CC modes of consumption will be impeded by a consumer reluctance to take risks in certain contexts. Risk (perceived or otherwise) must be clearly identified and mitigated in each service context, if shared service models are to be successful. Current resource use in the built inner-city environment is not sustainable; however, consumers have been slow to change. Previous literature has indicated that a consumer stated attitude regarding CC does not necessarily translate to actual behaviors, and, in the transport context, the current research confirms that while consumers have a relatively high intent to engage with shared services, their preference is for traditional models of access and ownership. Where risk is identified as a key factor in this choice, future research should seek to explore the notion of perceived risk in specific collaborative consumption contexts, examining the nature and weight of that risk in consumer decisions to share or not to share.

The current study is, however, limited by the small sample gathered. Small samples general means that it may be more difficult during the analysis to identify significant results, as a large sample size provides greater power for detecting effect sizes. However, some key significant differences were found in the analysis of the current sample despite this, deeming this sample acceptable for the nature of the study (as a pilot, exploring consumer attitudes to as yet untested, new models of parking accessibility). This research identifies that consumers have a relatively high intent to engage with shared parking services. Future research should thus seek to conduct trial experiments of the car-parking concept to see if intention translates into actual behavior. Since this study was conducted, two of the major organizations whose employees took part have implemented such trial programs, and it is the intention of the authors to further understanding of the issue by researching consumer response to these trials.

Author Contributions: Conceptualization, L.M. and G.B.; Methodology, L.M. and G.B.; Validation, G.B.; Formal Analysis; Investigation.; Data Curation, G.B.; Writing-Original Draft Preparation, L.M.; Writing-Review and Editing, L.M.; Visualization, L.M.; Supervision, L.M.

Funding: This research received no external funding. 
Acknowledgments: Oakwood Properties LTD, New Zealand (https:/ / oakwoodproperties.co.nz/)—research scholarship support.

Conflicts of Interest: The authors declare no conflict of interest.

\section{Appendix A}

Table A1. Factor Analysis Summary.

\begin{tabular}{|c|c|c|c|c|}
\hline Factors & $\begin{array}{c}\text { Factor } \\
\text { Loading }\end{array}$ & KMO & $\begin{array}{l}\text { Total Variance } \\
\text { Explained }\end{array}$ & $\begin{array}{l}\text { Cronbach's } \\
\text { Alpha }\end{array}$ \\
\hline Intention toward CC in General & & 0.829 & $68.0 \%$ & 0.910 \\
\hline $\begin{array}{l}\text { It is likely that I will frequently participate in collaborative } \\
\text { consumption communities when they are available. }\end{array}$ & 0.835 & & & \\
\hline I intend to engage in collaborative consumption often in the future. & 0.805 & & & \\
\hline $\begin{array}{l}\text { I can see myself seeking out collaborative consumption } \\
\text { opportunities in the future. }\end{array}$ & 0.802 & & & \\
\hline $\begin{array}{l}\text { Overall, sharing resources within a collaborative consumption } \\
\text { community is attractive to me. }\end{array}$ & 0.758 & & & \\
\hline $\begin{array}{l}\text { Engaging in collaborative consumption would be a hindrance to the } \\
\text { way I like to live my life. }\end{array}$ & -0.721 & & & \\
\hline Reputation & & 0.829 & $68.0 \%$ & 0.898 \\
\hline $\begin{array}{l}\text { I would gain recognition from others for being part of a } \\
\text { collaborative consumption community. }\end{array}$ & 0.917 & & & \\
\hline $\begin{array}{l}\text { Being part of a collaborative consumption community would } \\
\text { improve my social image. }\end{array}$ & 0.880 & & & \\
\hline $\begin{array}{l}\text { I would earn respect from others by sharing resources with } \\
\text { other people. }\end{array}$ & 0.735 & & & \\
\hline $\begin{array}{l}\text { People who share resources have more prestige than those who } \\
\text { do not. }\end{array}$ & 0.705 & & & \\
\hline Sustainability & & 0.829 & $68.0 \%$ & 0.902 \\
\hline Collaborative consumption is a sustainable mode of consumption. & 0.812 & & & \\
\hline $\begin{array}{l}\text { With the use of collaborative consumption, I demonstrate } \\
\text { environment friendly consumption behavior. }\end{array}$ & 0.794 & & & \\
\hline Collaborative consumption helps save resources. & 0.756 & & & \\
\hline Collaborative consumption is environment friendly. & 0.724 & & & \\
\hline Collaborative consumption is just a fad, and not necessary. & -0.632 & & & \\
\hline By sharing, I reduce my use of resources, which is a good thing. & 0.526 & & & \\
\hline Smartphone Capability & & 0.829 & $68.0 \%$ & 0.878 \\
\hline $\begin{array}{l}\text { I believe my smartphone will provide me a convenient method to } \\
\text { share resources. }\end{array}$ & 0.826 & & & \\
\hline $\begin{array}{l}\text { I believe my smartphone will be useful for } \\
\text { collaborative consumption. }\end{array}$ & 0.821 & & & \\
\hline Difficulties in CC & & 0.829 & $68.0 \%$ & 0.793 \\
\hline $\begin{array}{l}\text { There is too much risk associated with collaborative consumption } \\
\text { for me to become involved. }\end{array}$ & 0.775 & & & \\
\hline I do not trust other consumers enough to share resources with them. & 0.670 & & & \\
\hline $\begin{array}{l}\text { Seeking out opportunities for collaborative consumption is too } \\
\text { difficult for me. }\end{array}$ & 0.638 & & & \\
\hline $\begin{array}{l}\text { I believe collaborative consumption will be difficult to manage and } \\
\text { be a part of. }\end{array}$ & 0.469 & & & \\
\hline Attitude-Scenario One & & 0.804 & $62.7 \%$ & 0.889 \\
\hline $\begin{array}{l}\text { I do not like the idea of sharing a pool of carparks and would prefer } \\
\text { to lease one by myself. }\end{array}$ & 0.918 & & & \\
\hline $\begin{array}{l}\text { I believe a shared parking resource substitutes quite well for an } \\
\text { individually leased carpark. }\end{array}$ & -0.862 & & & \\
\hline Shared car parking will limit my freedom and flexibility. & 0.759 & & & \\
\hline $\begin{array}{l}\text { I think sharing a carpark will cause me time management issues } \\
\text { and stress. }\end{array}$ & 0.701 & & & \\
\hline $\begin{array}{l}\text { The shared parking concept is just as good as an individually leased } \\
\text { carpark. }\end{array}$ & -0.693 & & & \\
\hline Attitude-Scenario Two & & 0.681 & $52.5 \%$ & 0.758 \\
\hline $\begin{array}{l}\text { As the main lease holder, I should be entitled to use the park } \\
\text { outside of my work hours, at no cost. }\end{array}$ & 0.824 & & & \\
\hline $\begin{array}{l}\text { I consider this model to be profiteering on the part of the park } \\
\text { owner, and not considerate of my needs. }\end{array}$ & 0.694 & & & \\
\hline I believe after hours usage by others will cause me problems. & 0.642 & & & \\
\hline Behavioral Intention-Scenario One & & 0.726 & $69.3 \%$ & 0.868 \\
\hline $\begin{array}{l}\text { In the future, I am likely to choose a sharing program like the } \\
\text { parking concept instead of an individually leased carpark. }\end{array}$ & 0.885 & & & \\
\hline $\begin{array}{l}\text { I am prepared to pay more to lease a carpark individually, than to } \\
\text { share a pool of parks with other users. }\end{array}$ & -0.851 & & & \\
\hline $\begin{array}{l}\text { I need a car park. In the future, I would prefer a sharing option like } \\
\text { this to an individually leased carpark. }\end{array}$ & 0.756 & & & \\
\hline
\end{tabular}


Table A1. Cont.

\begin{tabular}{|c|c|c|c|c|}
\hline Factors & $\begin{array}{c}\text { Factor } \\
\text { Loading }\end{array}$ & KMO & $\begin{array}{l}\text { Total Variance } \\
\text { Explained }\end{array}$ & $\begin{array}{c}\text { Cronbach's } \\
\text { Alpha }\end{array}$ \\
\hline Behavioral Intention-Scenario Two & & 0.610 & $35.1 \%$ & 0.594 \\
\hline $\begin{array}{l}\text { I would prefer to control the carpark, determining when it was } \\
\text { available to others, and other user fees be deducted from my } \\
\text { weekly rental. }\end{array}$ & 0.758 & & & \\
\hline $\begin{array}{l}\text { I do not use my carpark all day on weekdays and am happy for } \\
\text { other users to use the park when I do not require it, with no } \\
\text { financial benefit to me, if there was an easy way to manage this. }\end{array}$ & -0.517 & & & \\
\hline I would rather pay more to lease the carpark $24 \mathrm{~h}$ on weekdays. & 0.458 & & & \\
\hline
\end{tabular}

\section{Appendix B}

Table A2. Summary of Motivational Determinants of Collaborative Consumption.

\begin{tabular}{|c|c|c|c|}
\hline Factors & Mean & $\begin{array}{c}\text { Std. } \\
\text { Deviation }\end{array}$ & Analysis N \\
\hline \multicolumn{4}{|l|}{ Intention toward CC in General } \\
\hline $\begin{array}{l}\text { It is likely that I will frequently participate in collaborative } \\
\text { consumption communities when they are available. }\end{array}$ & 3.51 & 1.455 & 89 \\
\hline I intend to engage in collaborative consumption often in the future. & 3.64 & 1.517 & 89 \\
\hline $\begin{array}{l}\text { I can see myself seeking out collaborative consumption } \\
\text { opportunities in the future. }\end{array}$ & 3.62 & 1.592 & 89 \\
\hline $\begin{array}{l}\text { Overall, sharing resources within a collaborative consumption } \\
\text { community is attractive to me. }\end{array}$ & 3.26 & 1.549 & 89 \\
\hline $\begin{array}{l}\text { Engaging in collaborative consumption would be a hindrance to the } \\
\text { way I like to live my life. }\end{array}$ & 3.93 & 1.468 & 89 \\
\hline \multicolumn{4}{|l|}{ Reputation } \\
\hline $\begin{array}{l}\text { I would gain recognition from others for being part of a } \\
\text { collaborative consumption community. }\end{array}$ & 4.37 & 1.171 & 89 \\
\hline $\begin{array}{l}\text { Being part of a collaborative consumption community would } \\
\text { improve my social image. }\end{array}$ & 4.38 & 1.123 & 89 \\
\hline $\begin{array}{l}\text { I would earn respect from others by sharing resources with } \\
\text { other people. }\end{array}$ & 4.19 & 1.137 & 89 \\
\hline $\begin{array}{l}\text { People who share resources have more prestige than those who } \\
\text { do not. }\end{array}$ & 4.87 & 1.350 & 89 \\
\hline \multicolumn{4}{|l|}{ Sustainability } \\
\hline Collaborative consumption is a sustainable mode of consumption. & 2.63 & 1.219 & 89 \\
\hline $\begin{array}{l}\text { With the use of collaborative consumption, I demonstrate } \\
\text { environment friendly consumption behavior. }\end{array}$ & 2.58 & 1.176 & 89 \\
\hline Collaborative consumption helps save resources. & 2.26 & 1.133 & 89 \\
\hline Collaborative consumption is environment friendly. & 2.73 & 1.241 & 89 \\
\hline Collaborative consumption is just a fad, and not necessary. & 5.20 & 1.341 & 89 \\
\hline By sharing, I reduce my use of resources, which is a good thing. & 2.46 & 1.289 & 89 \\
\hline \multicolumn{4}{|l|}{ Smartphone Capability } \\
\hline $\begin{array}{l}\text { I believe my smartphone will provide me a convenient method to } \\
\text { share resources. }\end{array}$ & 3.15 & 1.442 & 89 \\
\hline $\begin{array}{l}\text { I believe my smartphone will be useful for } \\
\text { collaborative consumption. }\end{array}$ & 3.12 & 1.684 & 89 \\
\hline \multicolumn{4}{|l|}{ Financial Drivers } \\
\hline $\begin{array}{l}\text { I would participate in collaborative consumption even if there was } \\
\text { no financial benefit to doing so. }\end{array}$ & 3.74 & 1.450 & 89 \\
\hline $\begin{array}{l}\text { I would only participate in collaborative consumption if it saved } \\
\text { me money. }\end{array}$ & 3.62 & 1.722 & 89 \\
\hline \multicolumn{4}{|l|}{ Difficulties in CC } \\
\hline $\begin{array}{l}\text { There is too much risk associated with collaborative consumption } \\
\text { for me to become involved. }\end{array}$ & 4.57 & 1.278 & 89 \\
\hline I do not trust other consumers enough to share resources with them. & 4.18 & 1.266 & 89 \\
\hline $\begin{array}{l}\text { Seeking out opportunities for collaborative consumption is too } \\
\text { difficult for me. }\end{array}$ & 3.89 & 1.292 & 89 \\
\hline $\begin{array}{l}\text { I believe collaborative consumption will be difficult to manage and } \\
\text { be a part of. }\end{array}$ & 3.67 & 1.460 & 89 \\
\hline
\end{tabular}




\section{Appendix C Regression Assumptions}

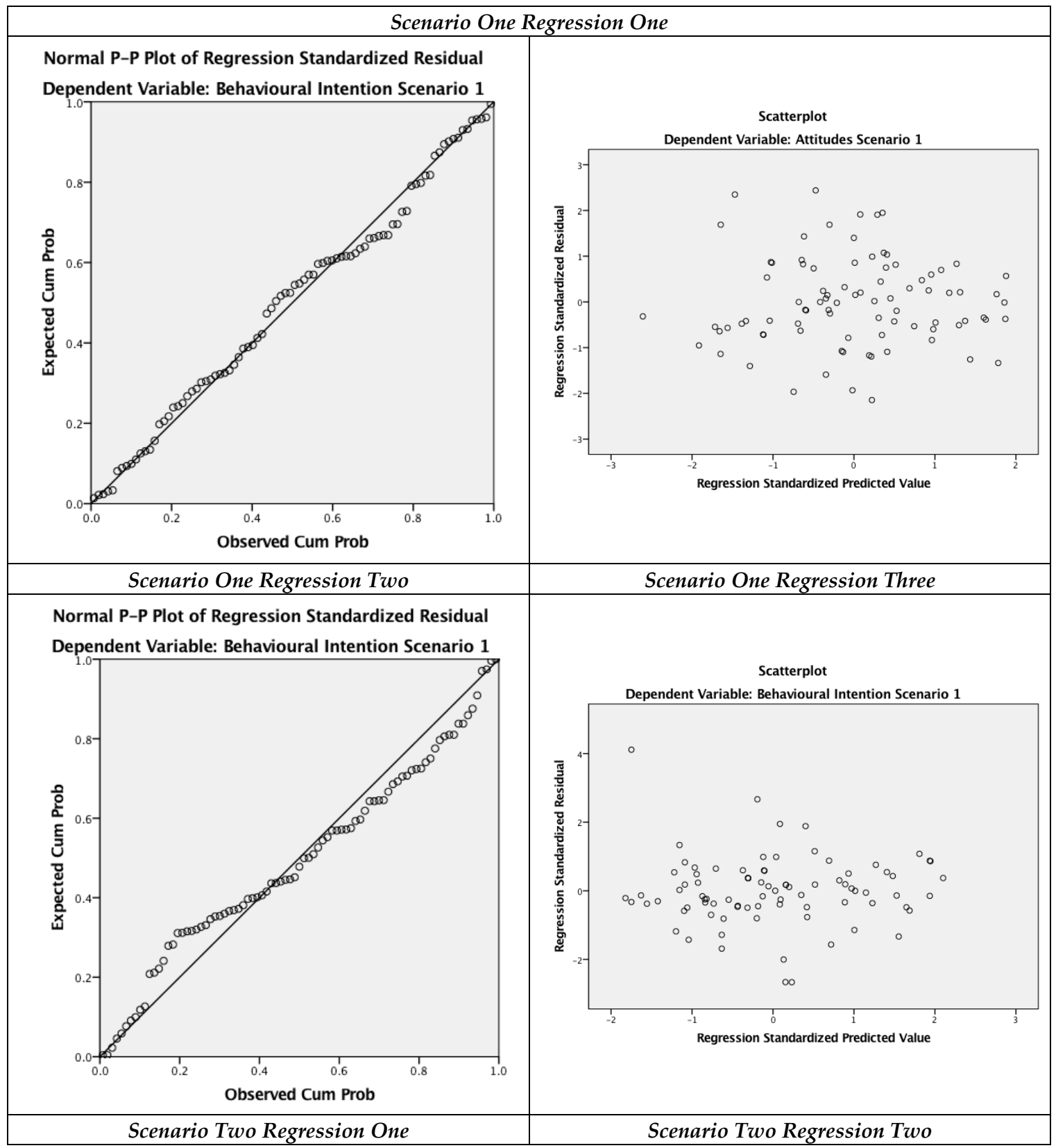




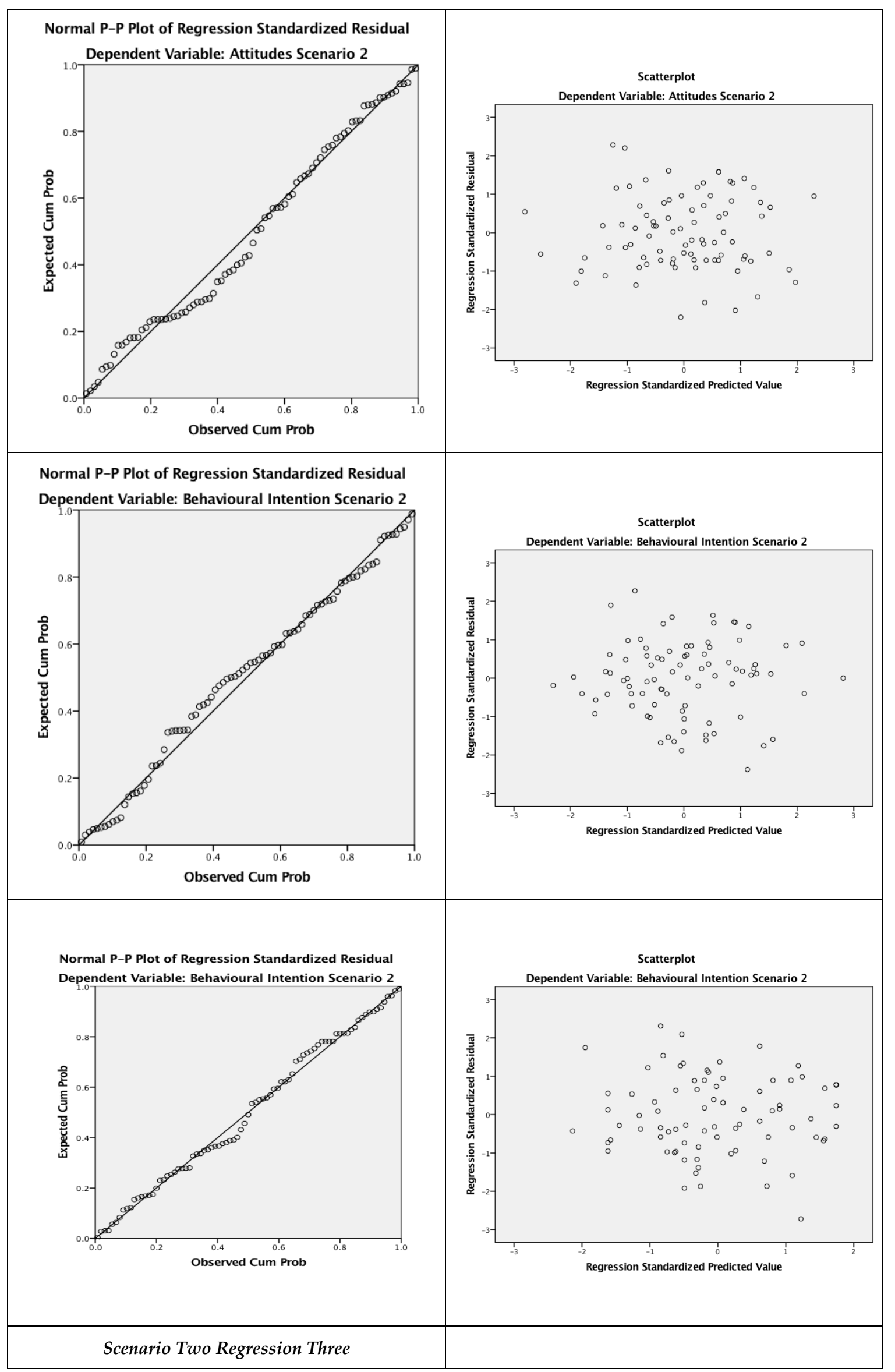




\section{References}

1. Scaraboto, D. Selling. Sharing, and Everything In Between: The Hybrid Economies of Collaborative Networks. J. Consum. Res. 2015, 42, 152-176. [CrossRef]

2. Botsman, R.; Rogers, R. What's Mine is Yours: The Rise of Collaborative Consumption; Harper Collins: New York, NY, USA, 2010.

3. Hamari, J.; Sjöklint, M.; Ukkonen, A. The sharing economy: Why people participate in collaborative consumption. J. Assoc. Inf. Sci. Technol. 2016, 67, 2047-2059. [CrossRef]

4. Möhlmann, M. Collaborative consumption: Determinants of satisfaction and the likelihood of using a sharing economy option again. J. Consum. Behav. 2007, 14, 193-207. [CrossRef]

5. Habibi, M.R.; Kim, A.; Laroche, M. From Sharing to Exchange: An Extended Framework of Dual Modes of Collaborative Nonownership Consumption. J. Assoc. Consum. Res. 2016, 1, 277-294. [CrossRef]

6. Bardhi, F.; Eckhardt, G.M. Access-Based Consumption: The Case of Car Sharing. J. Consum. Res. 2012, 39, 881-898. [CrossRef]

7. Nica, E.; Potcovaru, A. The Social Sustainability of the Sharing Economy. Econ. Manag. Financ. Mark. 2015, 10, 69-75.

8. Pojani, D.; Stead, D. Sustainable Urban Transport in the Developing World: Beyond Megacities. Sustainability 2015, 7, 7784-7805. [CrossRef]

9. Hayashi, Y.; Doi, K.; Yagishita, M.; Kuwata, M. Urban Transport Sustainability: Asian Trends. Problems and Policy Practices. Eur. J. Transp. Infrastruct. Res. 2004, 4, 27-45.

10. Nijkamp, P. In search of a transport policy research agenda. Int. J. Transp. Econ. 2006, 33, 141-167.

11. Available online: https://www.building.govt.nz/building-code-compliance/ (accessed on 20 August 2018).

12. Stubbs, M. Car Parking and Residential Development: Sustainability. Design andPlanning Policy, and Public Perceptions of Parking Provision. J. Urban Des. 2006, 7, 213-237. [CrossRef]

13. Belk, R. You are what you can access: Sharing and collaborative consumption online. J. Bus. Res. 2014, 67, 1595-1600. [CrossRef]

14. Van der Waerden, P.; Borgers, A.; Timmermans, H. Attitudes and Behavioural Responses to Parking Measures. Eur. J. Transp. Infrastruct. Res. 2006, 6, 301-312.

15. Matzler, K.; Veider, V.; Kathan, W. Adapting to the sharing economy. MIT Sloan Manag. Rev. 2015, 56, 71-77.

16. Belk, R. Possessions and the Extended Self. J. Consum. Res. 1988, 15, 139-168. [CrossRef]

17. Snare, F. The Concept of Property. Am. Philos. Q. 1972, 9, 200-206.

18. John, N.A. The social logics of sharing. Commun. Rev. 2013, 16, 113-131. [CrossRef]

19. Belk, R. Extended Self in a Digital World. J. Consum. Res. 2013, 40, 477-500. [CrossRef]

20. Cohen, B.; Kietzmann, J. Ride On! Mobility Business Models for the Sharing Economy. Org. Environ. 2014, 27, 279-296. [CrossRef]

21. Bamburg, S.; Fujii, S.; Friman, M.; Gärling, T. Behaviour theory and soft transport policy measures. Transp. Policy 2011, 18, 228-235. [CrossRef]

22. Stopher, P.R. Reducing road congestion: A reality check. Transp. Policy 2004, 11, 117-131. [CrossRef]

23. Piscicelli, L.; Cooper, T.; Fisher, T. The role of values in collaborative consumption: Insights from a product-service system for lending and borrowing in the UK. J. Clean. Prod. 2015, 97, 21-29. [CrossRef]

24. Hardin, G. The Tragedy of the Commons. Science 1968, 162, 1243-1248. [PubMed]

25. Prothero, A.; Dobscha, S.; Freund, J.; Kilbourne, W.E.; Luchs, M.G.; Ozanne, L.K.; Thøgersen, J. Sustainable consumption: Opportunities for consumer research and public policy. J. Public Policy Mark. 2011, 30, 31-38. [CrossRef]

26. Tussyadiah, I.P. An Exploratory Study on Drivers and Deterrents of Collaborative Consumption in Travel. In Information and Communication Technologies in Tourism 2015, Proceedings of the International Conference, Lugano, Switzerland, 3-6 February 2015; Tussyadiah, I., Inversini, A., Eds.; Springer International Publishing: Basel, Switzerland, 2015; pp. 817-830.

27. Carrington, M.J.; Neville, B.A.; Whitwell, G.J. Why Ethical Consumers Don't Walk Their Talk: Towards a Framework for Understanding the Gap Between the Ethical Purchase Intentions and Actual Buying Behaviour of Ethically Minded Consumers. J. Bus. Eth. 2010, 97, 139-158. [CrossRef]

28. Ajzen, I.; Fishbein, M. Attitude-Behavior Relations: A Theoretical Analysis and Review of Empirical Research. Psychol. Bull. 1977, 84, 888-918. [CrossRef] 
29. Kroes, E.P.; Sheldon, R.J. Stated Preference Methods in Transport Research. J. Transp. Econ. Policy 1988, 22, $11-25$.

30. Hair, J.F.; Black, W.C.; Babin, B.J.; Anderson, R.E. Multivariate Data Analysis, 7th ed.; Pearson: Essex, UK, 2014.

31. Hair, J.F.; Anderson, R.E.; Tatham, R.L.; Black, W.C. Multivariate Data Analysis with Readings, 4th ed.; Prentice-Hall: Upper Saddle River, NJ, USA, 1995.

32. Cohen-Blankshtain, G.; Rotem-Minda, O. Key research themes on ICT and sustainable urban mobility. Int. J. Sustain. Transp. 2016, 10, 9-17. [CrossRef]

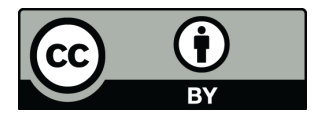

(c) 2018 by the authors. Licensee MDPI, Basel, Switzerland. This article is an open access article distributed under the terms and conditions of the Creative Commons Attribution (CC BY) license (http://creativecommons.org/licenses/by/4.0/). 